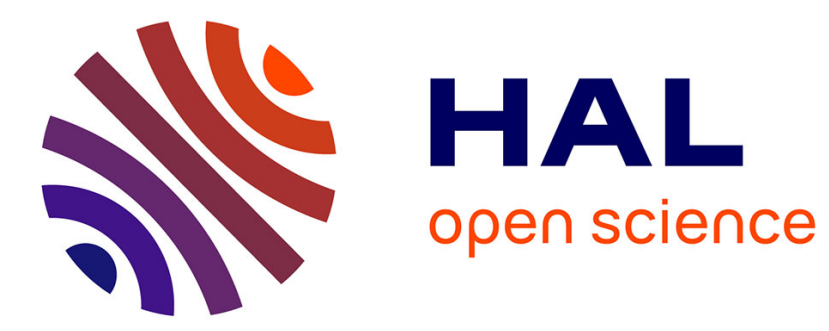

\title{
A new species of the genus Monokalliapseudes (Crustacea: Tanaidacea: Kalliapseudidae) from French Guiana
}

David T. Drumm, Jérôme Jourde, Pierrick Bocher

\section{- To cite this version:}

David T. Drumm, Jérôme Jourde, Pierrick Bocher. A new species of the genus Monokalliapseudes (Crustacea: Tanaidacea: Kalliapseudidae) from French Guiana. Proceedings of the Biological Society of Washington, 2015, 128 (1), pp.86-97. 10.2988/0006-324X-128.1.86 . hal-01245412

\section{HAL Id: hal-01245412 \\ https://hal.science/hal-01245412}

Submitted on 7 Feb 2020

HAL is a multi-disciplinary open access archive for the deposit and dissemination of scientific research documents, whether they are published or not. The documents may come from teaching and research institutions in France or abroad, or from public or private research centers.
L'archive ouverte pluridisciplinaire HAL, est destinée au dépôt et à la diffusion de documents scientifiques de niveau recherche, publiés ou non, émanant des établissements d'enseignement et de recherche français ou étrangers, des laboratoires publics ou privés. 
Send proofs to:

---David T. Drumm

---EcoAnalysts, Inc.

---Moscow, Idaho 83843, U.S.A.

---e-mail: ddrumm@ecoanalysts.com

\section{A new species of the genus Monokalliapseudes (Crustacea: Tanaidacea:}

\section{Kalliapseudidae) from French Guiana}

David T. Drumm*, Jérôme Jourde, and Pierrick Bocher

(DTD) EcoAnalysts, Inc., Moscow, Idaho 83843, e-mail: ddrumm@ecoanalysts.com;

(JJ, PB) UMR7266 LIENSs CNRS/University of La Rochelle, 2 rue Olympe de Gouges 17000 La Rochelle, France;

(JJ) OBIONE Biodiversity observatory, 2 rue Olympe de Gouges, 17000 La Rochelle, France

Abstract.---A new species, Monokalliapseudes guianae, is described from French Guianese estuaries. It is distinguishable from its only congener most notably by lacking an exopodite on pereopod 1 and by the nature of the basal article of the uropod. The inner distal corner of the basal article is only slightly produced and lacks a rounded lobe. The bases of pereopods 2 and 3 lack 
numerous long setae. Sexual dimorphism is observed in the antennule, cheliped, and pereopod 1. Depending on size, males can exhibit two forms of chelae. A new diagnosis is presented for the genus Monokalliapseudes.

Keywords: Tanaidacea, Kalliapseudes, Monokalliapseudes, French Guinea.

The genus Monokalliapseudes Lang, 1956 is easily distinguished from its confamilials by having a short and heavily setose dactylus on pereopod 6 , resembling the dactyli of pereopods 4 and 5. It was originally considered a subgenus of Kalliapseudes Lang, 1956 but was subsequently raised to full genus rank (Guţu 2006). It is a member of the subfamily Kalliapseudinae, which is distinguished from other kalliapseudids by having long plumose setae on the chelipeds, maxillipeds, and mandibular palps. Only one species has been described until now, Monokalliapseudes schubarti (Mané-Garzón, 1949), distributed from southeastern Brazil to Uruguay (Drumm \& Heard 2011, FreitasJúnior et al. 2013). It has been shown to be an important component of estuaries in southern Brazil, where it can reach high population densities and is a major food item of fish, crustaceans, and birds (Bemvenuti 1987, Leite 1995, Rosa-Filho \& Bemvenuti 1998, Montagnolli et al. 2004, Ferreira et al. 2005, Barreiros et al. 2009, Contente et al. 2009, 2012). 
The ECOCOT project has been implemented in order to explore French Guiana intertidal mudflat ecosystem structure and functioning. As part of this project, the monitoring survey of benthic communities from intertidal mudflats led to the discovery of a new species of Monokalliapseudes, in addition to the only two local tanaid species, Halmyrapseudes spansii Băcescu \& Guţu, 1975 and Discapseudes surinamensis Băcescu \& Guţu, 1975. We herein provide an illustrated description of the new species and present a new diagnosis for the genus. The genus is restricted to waters of the southwest Atlantic off South America.

Materials and Methods

Samples were collected in the infralittoral area of a bare mudflat bordered by mangroves and the Sinnamary River (Fig. 1) at low level of spring tide using a sediment hand-corer (150 mm diameter) at $20 \mathrm{~cm}$ depth, sieved on a $0.5 \mathrm{~mm}$ mesh size and preserved in $70 \%$ ethanol solution. Specimens were examined and dissected in glycerol. All drawings were prepared using a drawing tube on a Wild M12 microscope.

Specimens were measured from the tip of the rostrum to the posterior end of the pleotelson. Body width was measured on the widest part of the carapace. Terminology follows Larsen (2003). Type material is deposited at the National 
Museum of Natural History, Smithsonian Institution, Washington, D.C. (USNM) and the Muséum National d'Histoire Naturelle de Paris (MNHN).

Systematics

Family Kalliapseudidae Lang, 1956

Subfamily Kalliapseudinae Lang, 1956

Genus Monokalliapseudes Lang, 1956

Diagnosis (modified after Drumm \& Heard 2011).---Rostrum rounded. Pleotelson with simple setae on lateral and posterior margins. Antennule with biarticulate inner flagellum, showing sexual dimorphism in first peduncle article shape and number of aesthetascs. Antenna peduncle with five articles, last peduncle article with double row of plumose setae. Labium palp long and narrow, about 2.5 times as long as broad. Inner endite of maxillule with three setulate and one simple seta. Chelipeds showing strong sexual dimorphism; exopodite absent. Pereopod 1 exopodite present or absent. Pereopods 2 and 3 with proximal lobe of dactylus bearing several setae. Pereopod 6 basis with plumose setae on entire dorsal margin; dactylus short with numerous distal setae, very similar to dactylus of pereopods 4 and 5. Uropod basal article inner distal corner extended and bearing a simple seta.

Monokalliapseudes guianae, new species

Figs. 2--6 
Type locality.---Sinnamary estuary $\left(53^{\circ} 00^{\prime} 21.2^{\prime \prime} \mathrm{N}, 5^{\circ} 27^{\prime} 52.7^{\prime \prime} \mathrm{W}\right)$, French Guiana (Fig. 1).

Material examined.---Holotype (Entrée Fleuve, sample 66): 1 ovigerous $q$ (USNM 1273026) from type locality, 7.4 mm, 0 m, coll. P. Bocher, 27 May 2014. Allotype (Entrée Fleuve, sample 67): 1 đ̊ (USNM 1273027), 7.0 mm, 0 m, coll. P. Bocher, 27 May 2014. Paratypes (Entrée Fleuve, sample 66): 1 ovigerous $q$ (dissected), $9.0 \mathrm{~mm} ; 3$ ふึ ภ, $6.3 \mathrm{~mm}, 7.6 \mathrm{~mm}$ (dissected), $8.1 \mathrm{~mm}$ (USNM 1273028), 0 m, coll. P. Bocher, 27 May 2014; (Entrée Fleuve, sample 67): 1

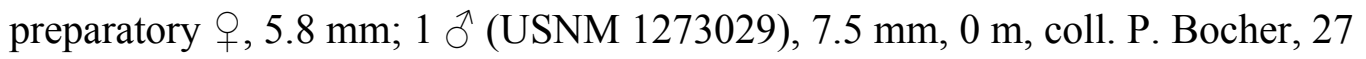
May 2014. Paratypes (Entrée Fleuve, sample 65): 2 우, $7.9 \mathrm{~mm}, 6.7 \mathrm{~mm}$ (complete specimens) (MNHN-IU-2013-18560), 0 m, coll. P. Bocher, 27 May 2014; (Entrée Fleuve, sample 66): 1 ovigerous $q, 8.6$ mm (complete specimen) (MNHN-IU-2013-18561), 0 m, coll. P. Bocher, 27 May 2014; (Entrée Fleuve, sample 67): 1 \& $6.7 \mathrm{~mm}$ (complete specimen) and 1 ๙ $7.6 \mathrm{~mm}$ (one cheliped missing) (MNHN-IU-2013-18562), 0 m, coll. P. Bocher, 27 May 2014; (Entrée Fleuve, sample 68) $2 \widehat{\jmath} \widehat{\jmath}, 5.6 \mathrm{~mm}, 5.5 \mathrm{~mm}$ (complete specimens) (MNHN-IU2013-18563), 0 m, coll. P. Bocher, 27 May 2014.

Diagnosis.---(Female) Pereopod 1 lacking exopodite; pereopods 2 and 3 lacking long dorsal setae on basis; inner distal corner of uropod slightly extended. (Male) Pereopod 1 with long plumose setae dorsally on basis, merus, and carpus. 
Description of holotype female.---Body (Fig. 2A): length approximately $7.4 \mathrm{~mm}, 7.5$ times as long as broad.

Carapace (Fig. 2A) slightly longer than broad, one pair mid-lateral setae; rostrum rounded.

Pereonites (Fig. 2A) 1 and 6 shortest and subequal, about 2.5 times as long as broad; 2--5 subequal, about 1.2 times as long as broad; each with one pair anterolateral setae; hyposphaenia absent on all pereonites.

Pleon (Fig. 2A) with pleonites subequal; epimera rounded, with several plumose setae (only setae bases are shown for pleopods 2-4); hyposphaenia absent. Pleotelson shorter than last three pleonites combined, narrowing posteriorly to a rounded tip, with simple setae on entire lateral and posterior margins.

Description of dissected paratype female (9.0 mm).---Antennule (Fig. 2B) first peduncle article approximately 2.1 times as long as second and third articles combined and approximately 2.2 times as long as maximum width, with some simple setae on inner margin and several simple and broom setae on outer margin. Second peduncle article 2.9 times shorter than first article, with several simple and broom setae. Third peduncle article slightly longer than fourth article, with several distal simple setae. Fourth peduncle article with several simple and broom setae near inner flagellum insertion. Outer flagellum shorter than first peduncle 
article, with eight articles, one aesthetasc on articles three, four, and six. Inner flagellum biarticulate, each article with one distal inner broom seta.

Antenna (Fig. 2C) first peduncle article with two simple setae on outer distal corner and medial extension bearing six plumose setae and short hairs on margins. Second peduncle article naked, squama bearing four simple setae. Third peduncle article with one simple seta on inner distal corner. Fourth peduncle article naked. Fifth peduncle article nearly same length as flagellum, with double row plumose setae and three broom setae proximally on outer margin. Flagellum with six articles, pectinate setae on articles 2--4, at least one plumose seta on articles 2--5, distal article with three terminal simple setae.

Labrum (Fig. 2D) slightly indented distally, finely setose. Clypeus with one pair of long simple setae.

Left mandible (Fig. 2E) incisor process and lacinia mobilis each with seven teeth; spine row with at least eight pectinate setae. Right mandible (Fig. 3A) incisor process with six teeth; spine row with about 10 pectinate setae. Palp uniarticulated with row of long plumose setae. Molar process (not illustrated) with typical grinding surface.

Labium (Fig. 3B) with hair-like setae on anterior and outer margins. Palp about 2.5 times as long as broad, with long hair-like setae on margins.

Maxillule (Fig. 3C) inner endite bearing three setulate setae and one short simple seta, hair-like setae distally on outer and inner margins. Outer endite with 
11 long and one short spiniform setae, one pectinate subterminal seta and dense rows of hair-like setae on outer margin.

Maxilla (Fig. 3D, E) with inner lobe of fixed endite bearing one posterior pectinate spiniform seta and with long anterior row of 20 plumose setae. Outer lobe of fixed endite with five thick pectinate setae, one long simple seta, several blunt-tipped setae, and one pectinate seta proximally on posterior face. Inner lobe of moveable endite with several blunt-tipped setae. Outer lobe of moveable endite with three pectinate and two setae bearing proximal setules and distal denticles. Outer margin with short hair-like setae.

Maxilliped (Fig. 3F) basal article fringed with plumose and hair-like setae on outer margin, inner margin naked. First article of palp with one subdistal simple seta. Second article with one simple seta on outer distal corner. Last three articles of palp with double row of long plumose setae on inner margin. Endite with several pappose setae, hair-like setae on distal margin, inner margin with three coupling hooks. Epignath not illustrated.

Cheliped (Fig. 4A, B) exopodite absent. Basis with two short simple setae on ventral margin. Merus longer than broad, with three simple setae. Carpus approximately 3.3 times as long as broad, with double row of long plumose setae ventrally and a row of simple setae dorsally. Propodus approximately 1.4 times as long as broad (excluding fixed finger), with diagonal row of plumose setae on inner face, several simple setae distally on inner and outer surfaces and near 
dactylus insertion; fixed finger with two ventral simple setae; cutting edge with about 18 spinules. Dactylus with three long pectinate setae on inner face and several short simple setae on inner and outer faces; cutting edge with eight teeth.

Pereopod 1 (Fig. 4C, D) exopodite absent. Basis with four simple setae. Ischium naked. Merus approximately two times as long as broad, approximately 1.8 times as long as carpus, with several simple setae ventrally and dorsally. Carpus with two ventrodistal and one dorsodistal spiniform setae and with several simple setae. Propodus shorter than carpus, with seven ventral and two dorsodistal spiniform setae; outer surface with several simple setae; inner surface with one subdistal pectinate seta; one broom seta on middorsal margin. Dactylus with numerous distal 'sensory' setae and inner surface with two proximal simple setae.

Pereopod 2 (Figs. 4E, 5A) basis approximately 2.3 times as long as broad, one broom and several short simple setae on dorsal margin, three ventral simple setae. Ischium with one simple ventrodistal seta. Merus same length as carpus, with several simple setae and one spiniform seta distally on inner surface. Carpus approximately 1.9 times as long as broad, with four spiniform setae on outer surface and one spiniform seta on inner surface; several simple setae. Propodus shorter than carpus, with five spiniform setae on outer and inner surfaces, several simple setae, and one broom seta midway on outer surface. Dactylus long and slender, shorter than basis, with one subdistal seta and two setae two-thirds length of dactylus; proximal lobe present, with ten setae. 
Pereopod 3 (Fig. 5B, C) similar to pereopod 2. Ischium with two setae. Carpus with eight spiniform setae. Dactylus with three subdistal and one proximal setae; proximal lobe with six setae.

Pereopod 4 (Fig. 5D, E) basis approximately 2.2 times as long as broad with two proximal broom setae and three short subdistal simple setae. Ischium with three simple setae. Merus subequal to carpus, with two spiniform and several simple setae. Carpus with eight spiniform setae on outer and inner surfaces; four simple setae. Propodus with seven inner and seven outer spiniform setae and one terminal spiniform seta; one terminal pectinate seta; two simple setae and one broom seta proximally on outer surface. Dactylus with 15 distal setae.

Pereopod 5 (Fig. 5F, G) similar to pereopod 4. Carpus with six outer and nine inner spiniform setae.

Pereopod 6 (Fig. 5H) smaller than the other pereopods. Basis approximately 3.8 times as long as broad, with 14 long plumose setae on dorsal margin and eight plumose setae on ventral margin. Ischium with four ventrodistal simple setae. Merus shorter than carpus, with three plumose setae on dorsal margin and five plumose setae on ventral margin. Carpus subequal to propodus, with six plumose setae on dorsal margin and seven plumose setae on ventral margin. Propodus with seven thick spiniform setae and about 24 smaller pectinate setae. Dactylus short, similar to dactylus of pereopods 4 and 5, with 11 distal setae. 
Pleopod (Fig. 6A) basal articles with five plumose setae. Exopodite with 22 and endopodite with 25 plumose setae.

Uropod (Fig. 6B) basal article approximately 2.1 times as long as broad, with inner distal corner slightly produced and bearing one simple seta. Exopodite with three articles, last article longest and bearing three simple setae. Endopodite with 13 articles.

Male.---Very similar to female but with following differences:

Antennule (Fig. 6C) first peduncle article long and narrow, approximately four times as long as broad. Outer flagellum with nine articles and six aesthetascs.

Cheliped (Fig. 6D, F) basis massive, with two short simple setae on ventral margin. Carpus approximately 2.8 times as long as broad, with double row of plumose setae ventrally and several simple setae on dorsal margin. Cheliped of male $7.6 \mathrm{~mm}$ in length (Fig. 6D) merus with large distal projection; propodus approximately 2.7 times as long as broad, with one large proximal and distal tooth on cutting edge; distal claw absent. Cheliped of male $6.3 \mathrm{~mm}$ in length (Fig. 6F) with distal projection of merus not as large; propodus approximately 1.7 times as long as broad; cutting edge with one large proximal tooth and seven spinules; distal claw present.

Pereopod 1 (Fig. 6E) basis, merus, and carpus with dorsal row of long plumose setae. 
Etymology.---The specific name refers to the region where it was collected, Guiana.

Distribution.---French Guiana estuaries (Fig. 1).

\section{Discussion}

The new species is placed in the genus Monokalliapseudes, even though it lacks an exopodite on the first pereopod, because this character was shown to be homoplastic (Drumm \& Heard 2011). It also shares several synapomorphies with Monokalliapseudes schubarti; for example, a pleotelson with simple setae along the lateral and posterior margins, a long and narrow labium palp, an inner endite of the maxillule with three setulate setae and one simple seta, the short dactylus of pereopod 6 , and the male cheliped with a massive basis. The clypeus (plate-like structure of cephalon, anterior to labrum) is rarely described in tanaidacean taxonomy, but its systematic importance has been shown in Kalliapseudidae (Drumm \& Heard 2011). The genera Cristapseudes Băcescu, 1980 and Phoxokalliapseudes Drumm \& Heard, 2011 possess cusps on the clypeus (erroneously stated as on the labrum in Drumm \& Heard 2011). The clypeus of M. guianae has a pair of long simple setae. If shown to be present in M. schubarti, this would be another synapomorphy of the genus.

Besides lacking an exopodite on the first pereopod, Monokalliapseudes guianae can be distinguished from $M$. schubarti by the inner distal corner of the 
basal article of the uropod being only slightly produced and lacking a rounded lobe, and the bases of pereopods 2 and 3 lacking numerous long setae.

Aspects of the biology and ecology of Monokalliapseudes schubarti have been intensively studied and have been shown to play an important ecological role in estuarine environments (Freitas-Júnior et al. 2013 and references therein). Since $M$. guianae also occupies similar habitats and is common and abundant, it is reasonable to suspect that it also plays a similarly important role.

\section{Acknowledgments}

This is part of the program ECOCOT (Fonctionnement de l'écosystème côtier guyanais) funded by the Europe community and the Région Guyane through FEDER funding. The OBIONE Biodiversity Observatory is financially supported by the Région Poitou-Charentes through CPER funding, University of La Rochelle and CNRS. We are grateful to Antoine Gardel and the CNRS Guyane for providing facilities for sampling on French Guiana mudflats. We gratefully thank Céline Artero, Vietkuong (Toni) Bui, Alexandre Carpentier, Christine Dupuy, Christel Lefrançois, and Pierre-Yves Pascal for their help during sampling. We are also grateful to Brendan "Chip" Barrett (EcoAnalysts, Inc.) for reviewing an early draft of the manuscript. 


\section{Literature Cited}

Băcescu, M. 1980. Contributions to the knowledge of some Kalliapseudidae (Crustacea, Tanaidacea) from the NW of the Indian Ocean. Travaux du Muséum National d'Histoire naturelle “Grigore Antipa” 22(2):359-379.

Băcescu, M., \& M. Guţu. 1975. A new genus (Discapseudes n. g.) and three new species of Apseudidae (Crustacea, Tanaidacea) from the northeastern coast of South America. Zoologische Mededelingen, Leiden 49(11):95113.

Barreiros, J. P., J. O. Branco, F. Freitas-Júnior, L. Machado, M. Hostim-Silva, \& J. R. Verani. 2009. Space-time distribution of the ichthyofauna from Saco da Fazenda Estuary, Itajaí, Santa Catarina, Brazil. Journal of Coastal Research 25(5):1114--1121.

Bemvenuti, C. E. 1987. Predation effects on a benthic community in estuarine soft sediments. Atlântica 9(1):5--32.

Contente, R. F., M. F. Stefanoni, \& H. L. Spach. 2009. Size-related changes in diet of the slipper sole Trinectes paulistanus (Actinopterygii, Achiridae) juveniles in a subtropical Brazilian estuary. Pan-American Journal of Aquatic Sciences 4(1):63--69. 
Contente, R. F., M. F. Stefanoni, \& H. L. Spach. 2012. Feeding ecology of the American freshwater goby Ctenogobius shufeldti (Gobiidae, Perciformes) in a sub-tropical estuary. Journal of Fish Biology 80(6):2357--2373.

Drumm, D. T., \& R. W. Heard. 2011. Systematic revision of the family Kalliapseudidae (Crustacea: Tanaidacea). Zootaxa 3142:1--172.

Ferreira, W. L. S., C. E. Bemvenuti, \& L. C. Rosa. 2005. Effects of the shorebirds predation on the estuarine macrofauna of the Patos Lagoon, south Brazil. Thalassas 21(2):77--82.

Freitas-Júnior, F., M. L. Christoffersen, J. P. de Araújo, \& J. O. Branco. 2013. Spatiotemporal distribution and population structure of Monokalliapseudes schubarti (Tanaidacea: Kalliapseudidae) in an estuary in southern Brazil. The Scientific World Journal 1--9.

Guţu, M. 2006. New Apseudomorph taxa (Crustacea, Tanaidacea) of the World Ocean. Bucaresti: Curtea Veche, 318 pp.

Lang, K. 1956. The Kalliapseudidae, a new family of Tanaidacea. In: K.G. Wingstrand, Bertil Hanström; zoological papers in honour of his $65^{\text {th }}$ birthday November $29^{\text {th }} 1956: 205-225$. (Zoologisk Institut Saertryk, Lund).

Larsen, K. 2003. Proposed new standardized terminology for tanaidacean Crustacea. Journal of Crustacean Biology 23(3):644-661. 
Leite, F. P. P. 1995. Distribuição temporal e especial de Kalliapseudes schubarti Mañé-Garzón, 1949 (Crustacea, Tanaidacea) na região do Araçá, São Sebastião (SP). Arquivos de Biologia e Tecnologia 38(2):605--618.

Mañé-Garzón, F. 1949. Un neuvo tanaidáceo ciego de Sud América, Kalliapseudes schubartii, nov. sp. Comunicaciones Zoológicas del Museo del Museo de Historia Natural de Montevideo 3(52):1-6.

Montagnolli, W., A. Zamboni, R. Luvizotto-Santos, \& J. S. Yunes. 2004. Acute effects of Microcystis aeruginosa from the Patos Lagoon Esturay, Southern Brazil, on the microcrustacean Kalliapseudes schubartii (Crustacea: Tanaidacea). Archives of Environmental Contamination and Toxicology 46(4):463--469.

Rosa-Filho, J. S., \& C. E. Bemvenuti. 1998. O sediment como fator limitante para a distribuição de Kalliapseudes schubartii Mañé-Garzón, 1949 (Crustacea, Tanaidacea) em fundos moles estuarinos. Nauplius 6:119--127. 
Figure Legends

Fig. 1. Map showing collection sites and type locality (star) of Monokalliapseudes guianae.

Fig. 2. Monokalliapseudes guianae. Ovigerous female. A, Holotype (USNM 1273026), habitus, dorsal (only setae bases are shown for pleopods 2-4); paratype, (USNM 1273028), B, antennule; C, antenna; D, clypeus and labrum; E, left mandible. Scale bars: $A=0.5 \mathrm{~mm}$; $\mathrm{B}-\mathrm{D}=0.01 \mathrm{~mm} ; \mathrm{E}=0.05 \mathrm{~mm}$.

Fig. 3. Monokalliapseudes guianae. Ovigerous female. (USNM 1273028A). A, right mandible; B, labium; C, maxillule; D, maxilla (anterior); E, maxilla (posterior). F, maxilliped. Scale bars: A, F $=0.1 \mathrm{~mm}$; B--E $=0.05 \mathrm{~mm}$.

Fig. 4. Monokalliapseudes guianae. Ovigerous female, (USNM 1273028). A, cheliped (outer). B, chela (inner). C, pereopod 1 (outer). D, pereopod 1 distal articles or carpus, propodus and dactylus (inner). E, pereopod 2 (outer). Scale bars $=0.1 \mathrm{~mm}$

Fig. 5. Monokalliapseudes guianae. Ovigerous female. (USNM 1273028). A, carpus and propodus of pereopod 2 (inner); B, pereopod 3 (inner); C, pereopod 
3 (outer); D, pereopod 4 (inner); E, pereopod 4 (outer); F, pereopod 5 (outer); G, pereopod 5 (inner); H, pereopod 6 (outer). Scale bars $=0.1 \mathrm{~mm}$.

Fig. 6. Monokalliapseudes guianae. Ovigerous female. (USNM 1273028). A, pleopod; B, uropod (ventral). Large male. C, antennule; D, cheliped (outer); E, pereopod 1 (inner). Small male. F, cheliped (outer). Scale bars: A--C, E, F = 0.1 $\mathrm{mm} ; \mathrm{D}=0.2 \mathrm{~mm}$. 
Figure 1

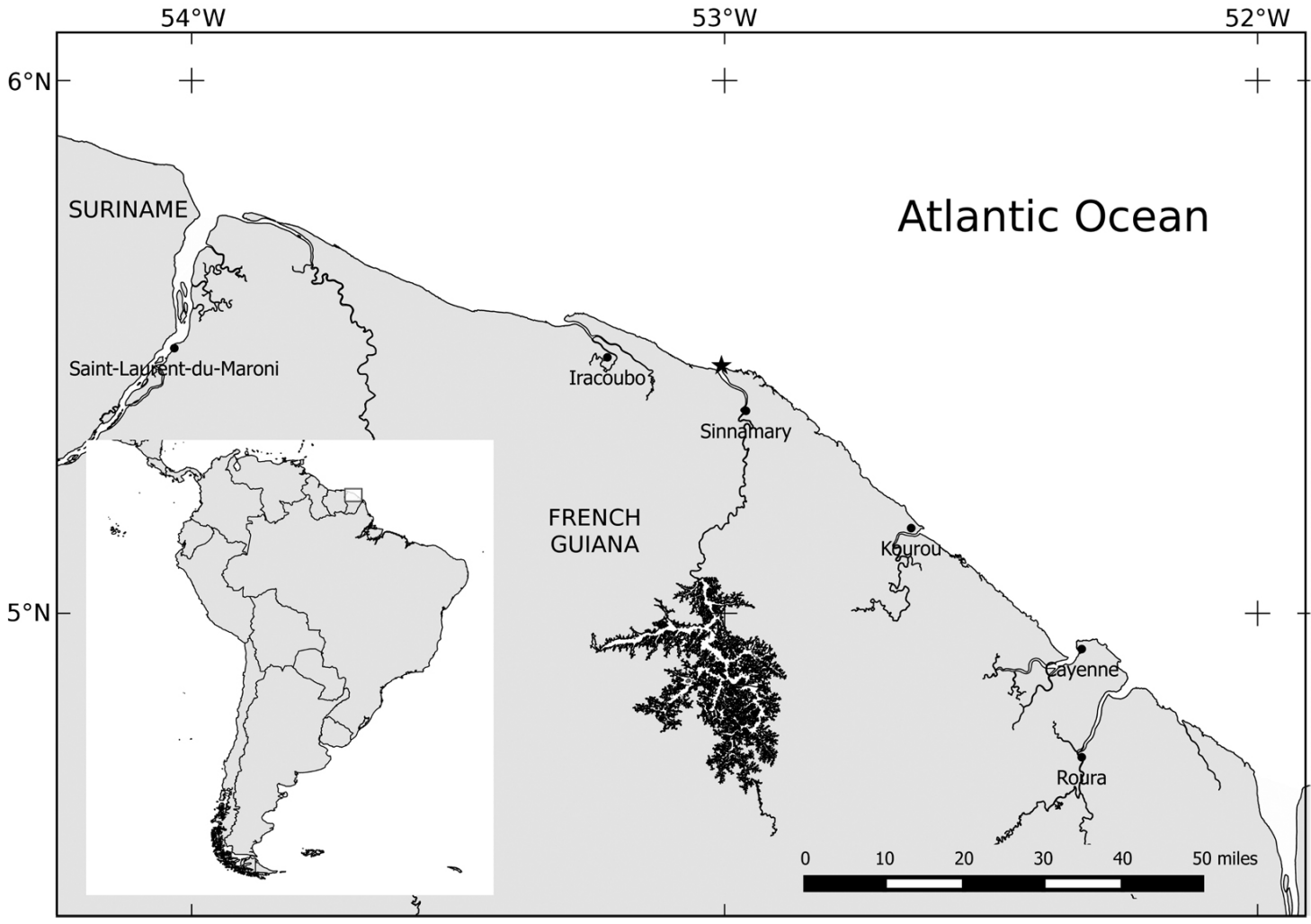


Figure 2

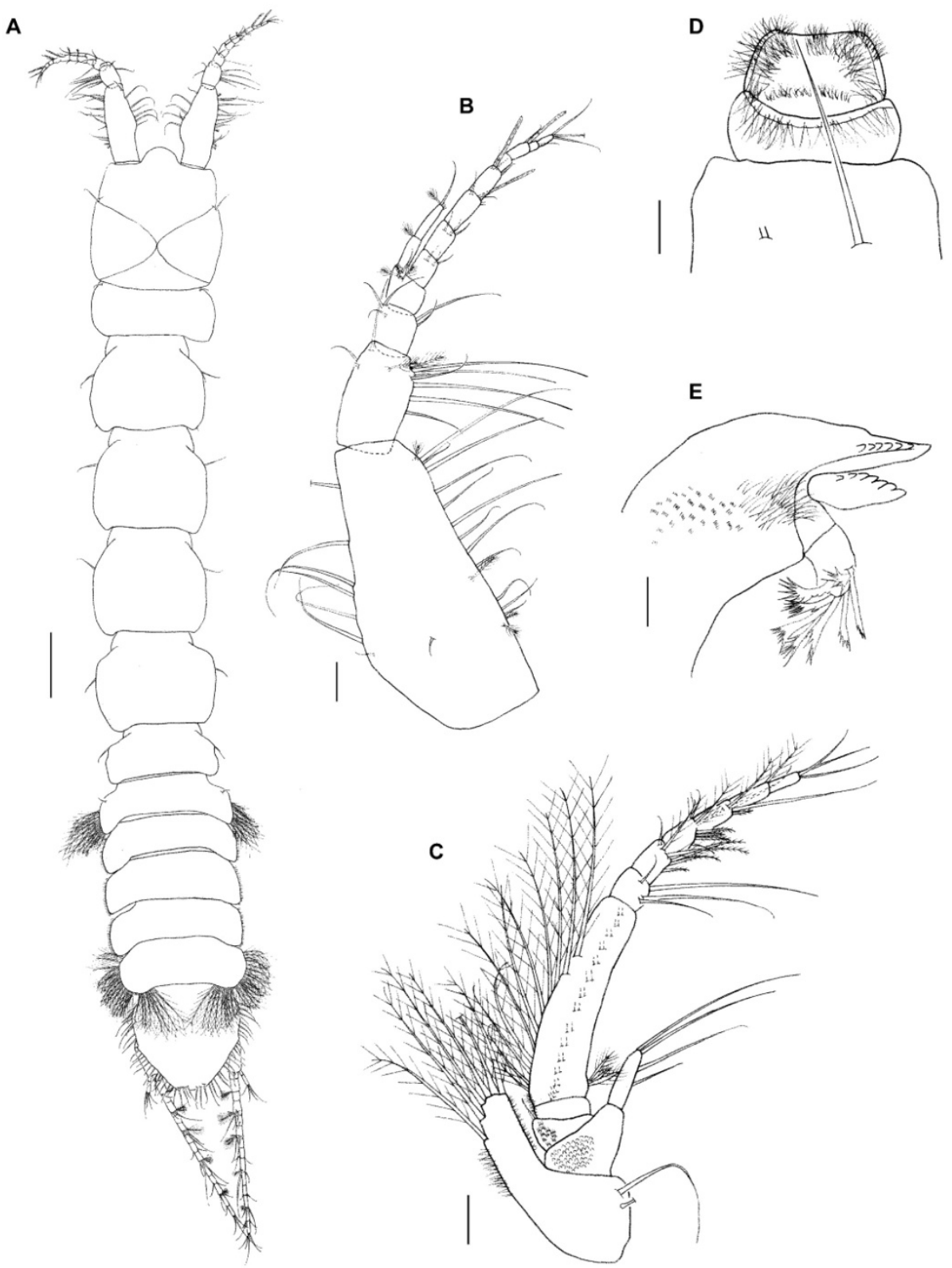


Figure 3

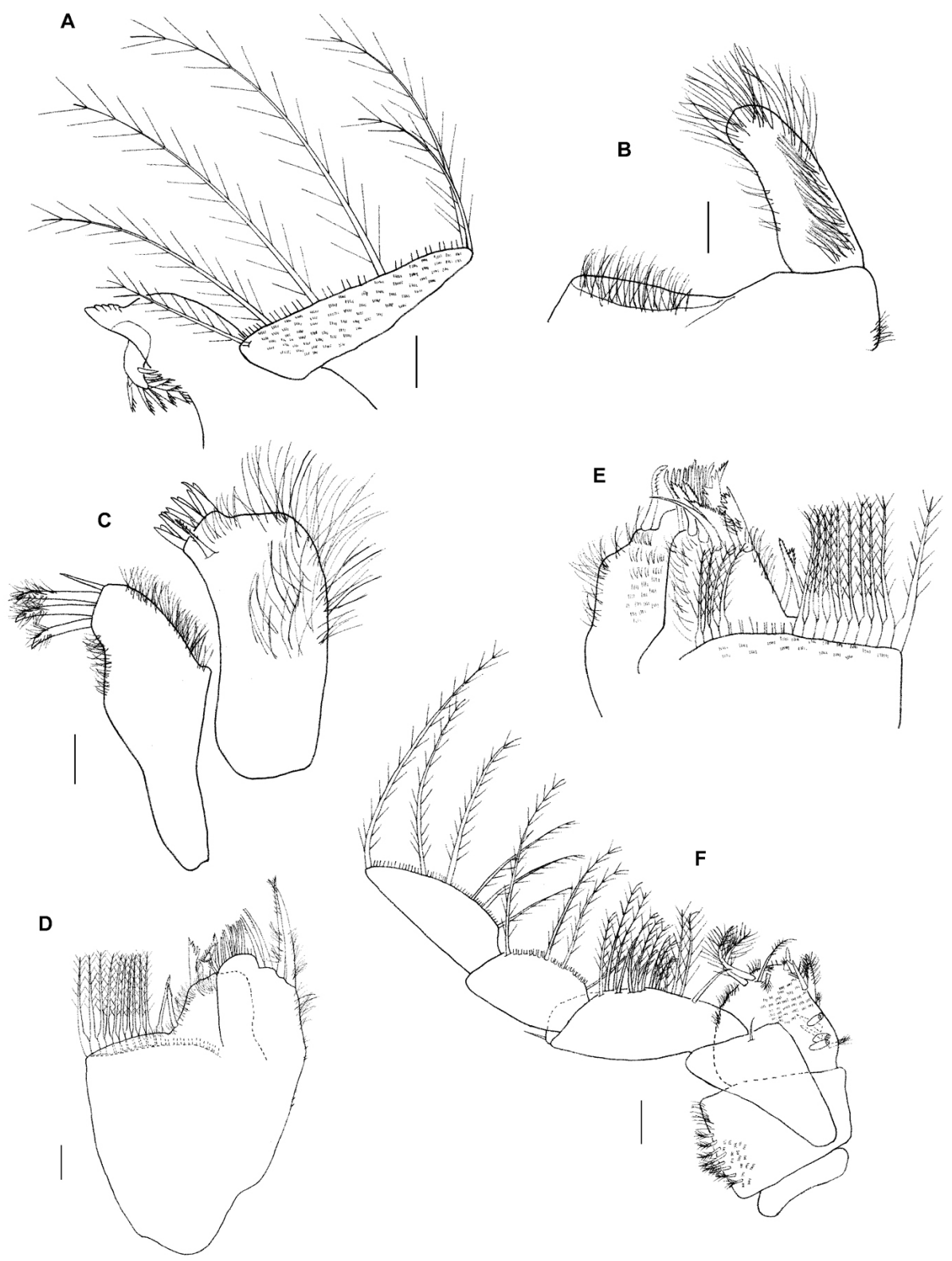


Figure 4

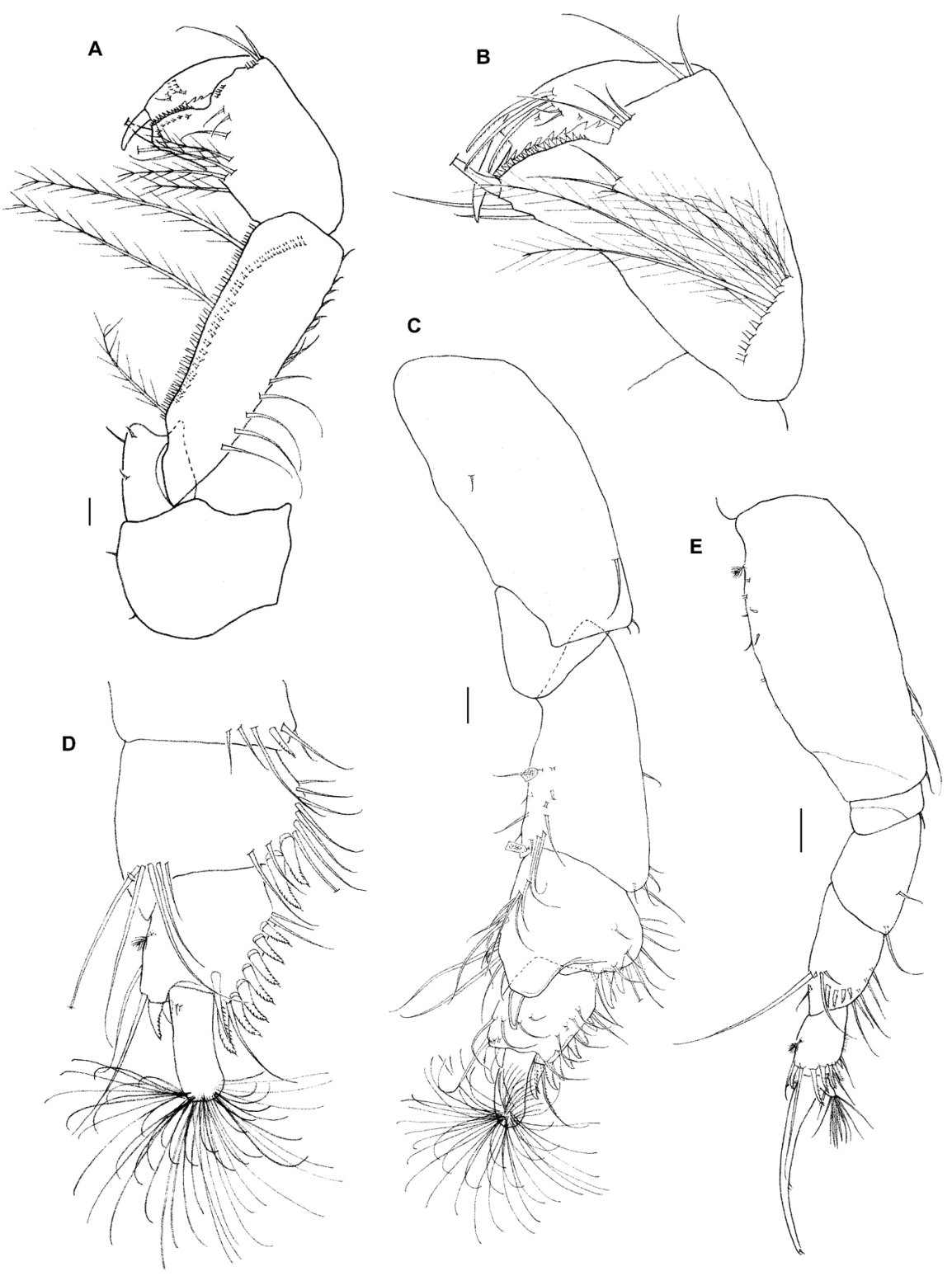


Figure 5

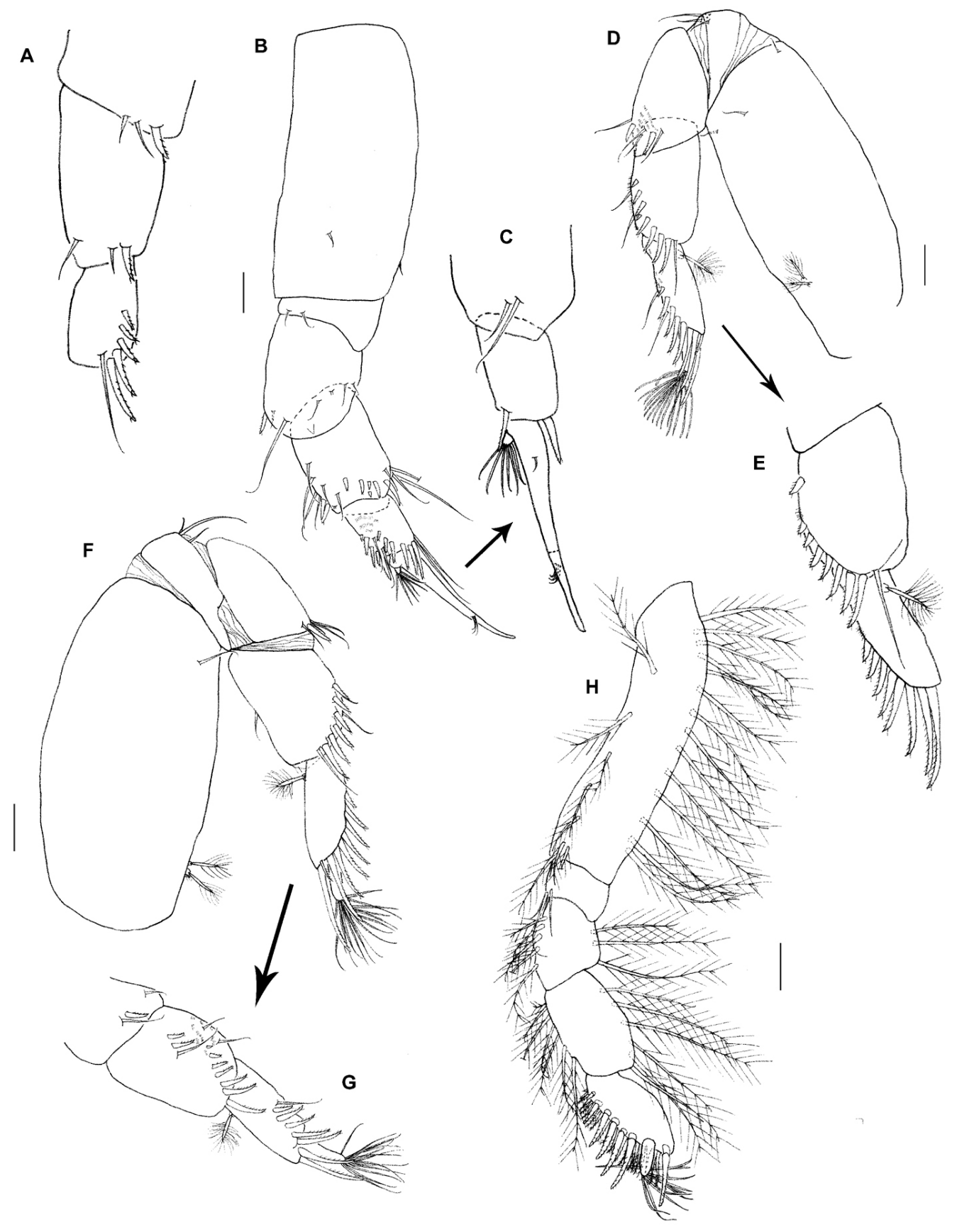


Figure 6

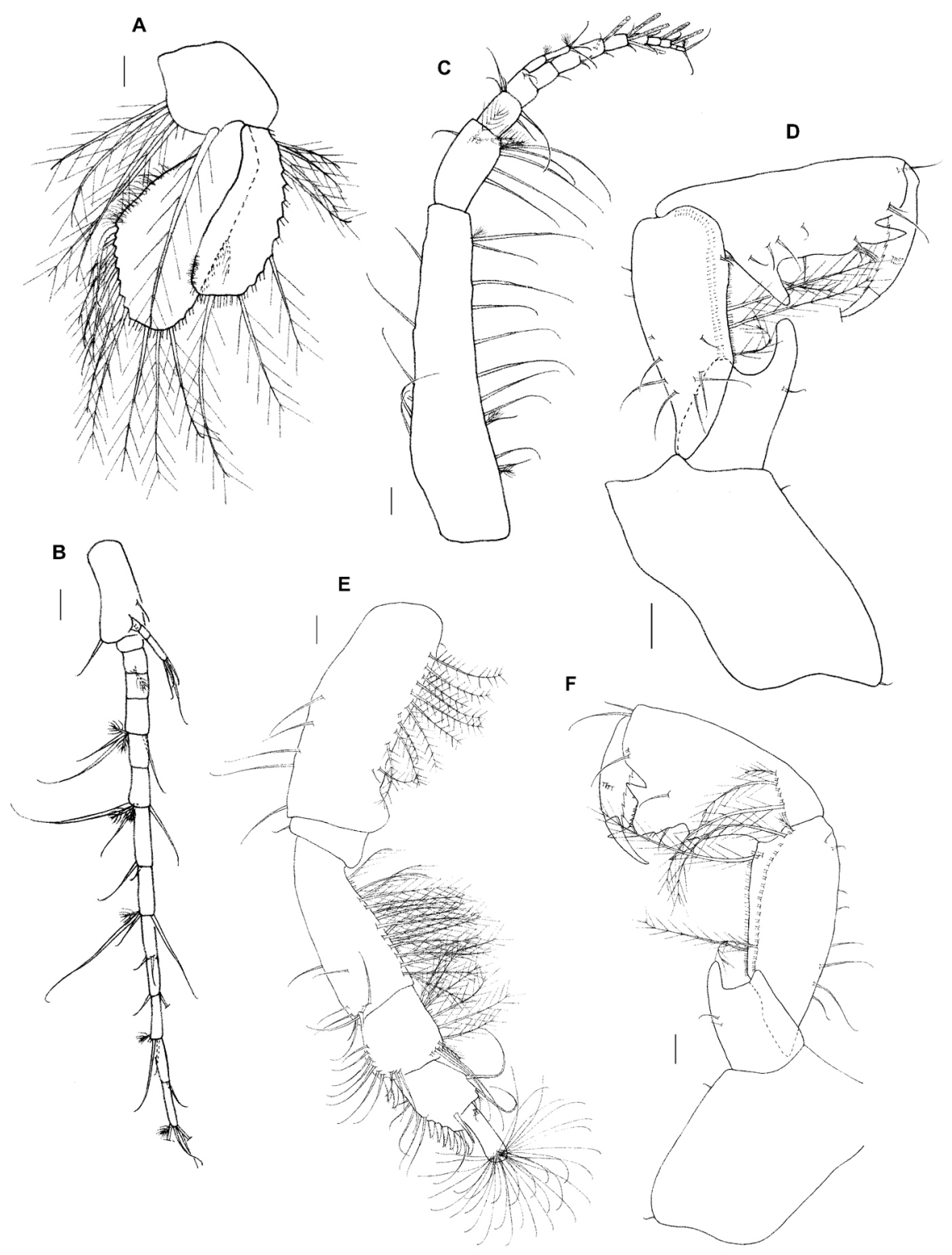

